\title{
The Affections of the Soul according to Aristotle, the Stoics and Galen: On Melancholy
}

DOI: $10.14746 / \mathrm{pea} .2020 .1 .5$

\author{
MARIA PROTOPAPAS-MARNELI \\ /Academy of Athens /
}

Galen of Pergamon (129-217? B.C. [Boudon-Millot 200o]), a prolific physician of the $2^{\text {nd }}$ century A.D., wished to be considered both a philosopher and a physician (Hankinson 2009: 184). According to Athenaeus of Naucratis, he wrote more philosophical and medical treatises than any of his predecessors, without of course being inferior as to his diagnoses to any physician prior to himself, as mentioned by the Naucratian: "Galen of Pergamum had published more treatises than all his predecessors and was not inferior to any of the ancient doctors in his diagnosis." Eusebius of Caesarea, who lived only few decades after Galen, reports that in his times, Galen was considered exceptionally

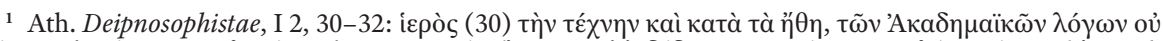

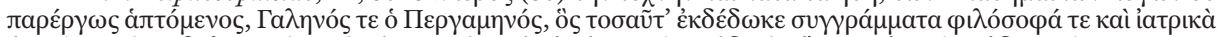

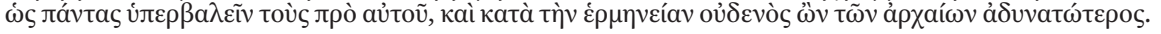


important, even when compared to Aristotle and Theophrastus. ${ }^{2}$ Moreover, the lexicon of Suda reports that Galen's treatises on medicine, philosophy, rhetoric, and grammar were so renowned that it was not necessary to make special reference to them. ${ }^{3}$ In order to determine how involved Galen was with philosophy, it suffices to study the list of his writings in his treatise, De libris propriis (Boudon-Millot 200o). Similarly, his treatise Quod optimus medicus sit quoque philosophus expresses the belief in the value of philosophy for training in logic prior to practising the art of Medicine, that is, as a prerequisite for correct diagnosis and consequently, the administration of the correct treatment method, which according to both Hippocrates and Galen ${ }^{4}$ is a factor of crucial importance in the healing of the patient. Indeed, in the same treatise, Galen's momentous reference to the virtues of a physician argues that a real one must be a friend of prudence and an ally of the truth (Gal. Med.Phil. 59, 10-11), invoking the virtues of the philosopher as recorded by Plato in the Republic. ${ }^{5}$ For the most part, however, Galen's philosophical works have been lost, while the ones that have come down to us are fragmentary in nature (BoudonMillot 2000: $457 \mathrm{ff}$.).

Galen's philosophical treatise De placitis Hippocratis et Platonis (PHP), ${ }^{6}$ which consists of nine books, refers to the content of the Stoic Chrysippus' treatise On Affec-

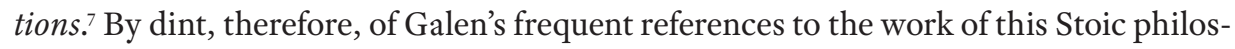
opher, information can be inferred as to its content, which otherwise would have been unknown to us. As a result, the treatise is invaluable for the perception of the Stoic Philosophy, particularly regarding the psychic affections, despite the difficult passages that are often encountered in Galen's text ${ }^{8}$ having their source in the well-known linguistic "difficulty" that characterizes Chrysippus' texts, which had been recognized already in antiquity. ${ }^{9}$

This specific treatise (along with others) give rise to the present study, which will focus on two lines: (a) the analysis of the affections of the soul according to the Stoics and

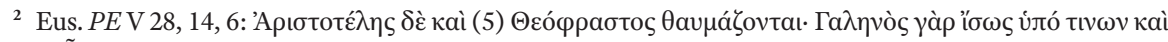

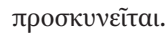

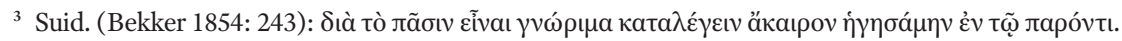

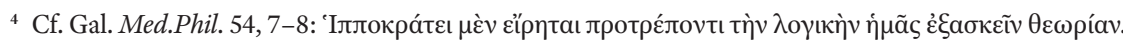

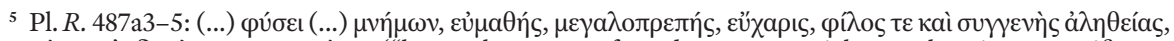

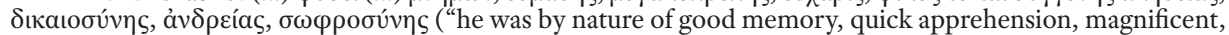
gracious, friendly and akin to truth, justice, bravery and sobriety").

${ }^{6}$ Gal. De placitis Hippocratis et Platonis libri novem (= PHP); De Lacy (1981). Here, I would like to make it precise that often I cite the Galenic treatises in their older editions (Kühn) because they are used by I. von Arnim whose fragments this article is based on.

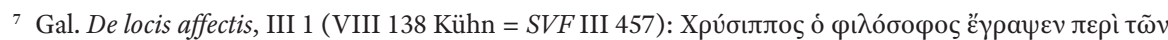

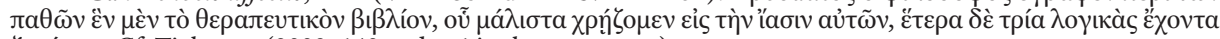

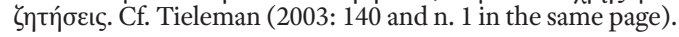

${ }^{8}$ Regarding the 1st book of Galen's treatise and a possible existence of a 10 ${ }^{\text {th }}$ book cf. De Lacy (1981: $44 \mathrm{ff}$.).

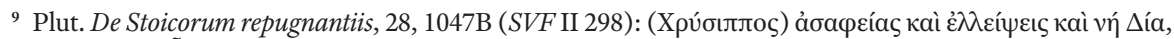

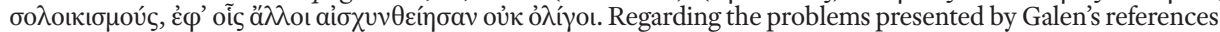
to Chrysippus's texts and the difficulties of comprehension that arise from the obscure language of the Stoic philosopher, cf. De Lacy (1981: 57). 
Galen, emphasizing Chrysippus' theory of the affections; and (b) the issue of melancholy as a psychic and physical affection, as approached by Galen and always compared with the knowledge he drew from physicians prior to him, such as Hippocrates and Rufus of Ephesus, as well as from philosophers, and thus mainly Aristotle and the Stoics.

\section{a) The affections of the soul according to the Stoics and Galen}

As Galen notes with a rather ironic touch, each of the four books in Chrysippus' homonymous treatise On affections is twice as long as his own treatise on the same subject. ${ }^{10}$ It is known that his treatise On the Opinions of Hippocrates and Plato is regarded as one of his most important philosophical works, ${ }^{11}$ since it is here that he mainly engages in the comparison, validation and analysis of Platonic, Hippocratic and Aristotelian theories. At the same time, he often draws on the theories of the Stoics, and especially Chrysippus $^{12}$ treatise on the affections of the soul. At times, Galen casts doubt on these theories, while at others, most likely unconsciously, he accepts them. ${ }^{13}$ Galen himself focuses on issues related to the soul, to its parts and to their functions. He places these parts in specific spots of the body ${ }^{14}$ while both exposing and criticizing theories pertaining to the psychic faculties, which are associated with the life of living organisms, and which are expressed as various vital actions and reactions. These are issues which had long been the focus of philosophical thinking par excellence, since they are related to reproduction, food, growth, and mental processes. The main concern here is those activities which are expressed through the senses, the affections and reasoning (Moraux 1985: 164). In the treatise in question, Galen refers to the Platonic theory on the division of the psyche into three parts and substantiates his own position of agreement, drawing his material from the Platonic dialogues, ${ }^{15}$ while he also refers to the Aristotelian theory on the unity of the soul, which posits a division into faculties. Galen identifies the reasoning soul as

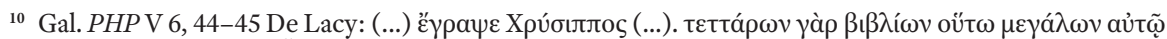

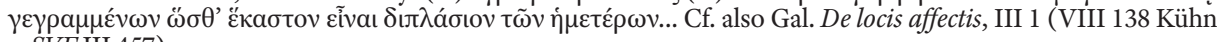
$=$ SVF III 457).

${ }^{11}$ Galen himself seems to consider it as very important, since, as he has already mentioned, he repeatedly returns, corrects, and enriches his text.

${ }^{12}$ Galen, referring to Chrysippus, writes that he adorned the city of Soloi with his birth, just as Aristotle

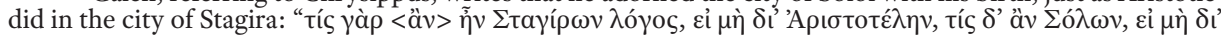

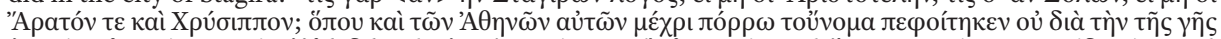

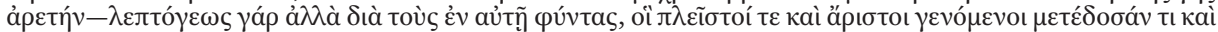

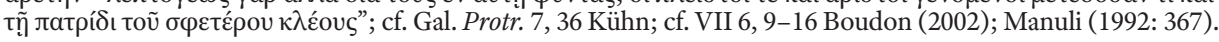

13 Cf. Moraux (1985: VII); Cheuvet (1857: 163-164); Manuli (1992: 368).

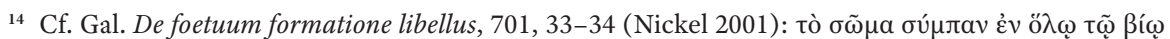

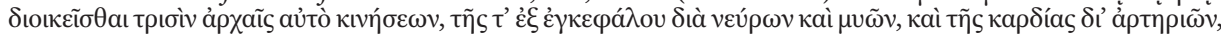

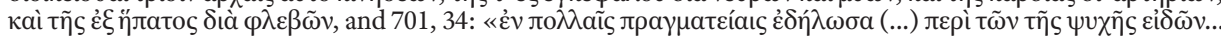

${ }_{15}$ His important references to the Platonic dialogues, especially to the Republic, the Sophist and the Timaeus; in this treatise he shows his deep preoccupation with the Platonic philosophy; the list of his works leads to the same conclusion. 
residing in the brain, rather than in the heart, as Aristotle ${ }^{16}$ and the Stoics had asserted. Galen's analysis and the presentation of his theory are performed in accordance with his scientific knowledge, which derives from his experience in anatomy, ${ }^{17}$ thus he presents more reliable arguments. ${ }^{18} \mathrm{He}$ seems to agree not only with Hippocrates' theory but also with the Platonic theory of the soul, while refuting the aforementioned Aristotelian and Chrysippian theory that the hegemonikon is located in the heart. ${ }^{19}$

In his 5 th book of $P H P$, Galen refers to the affections of the soul, that is, to the maladies which appear in its parts and finds correlations to physical illnesses. In other words, he holds that when the reasoning part of the soul is in conflict with its other parts, a psychical disorder ${ }^{20}$ appears, which corresponds to the body parts that are ill due to conflict arising from an imbalance in the four Hippocratic humors: the hot, the cold, the dry and the wet. According to Chrysippus, the health of the human body corresponds to

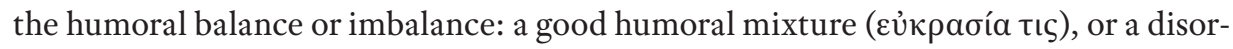

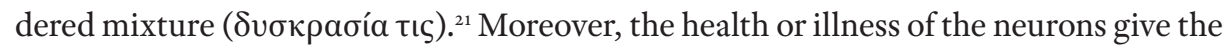
human body strength or weakness, that is eủtovía or átovía, while the symmetry or

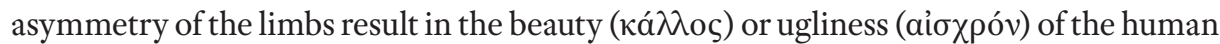
body.22 During an imaginary dialogue, Galen asks Chrysippus to proceed to the same correspondence since, on the health or the malady of the soul, Chrysippus stresses and Galen repeats that "the soul is the pneuma that is born and lives within us inhabiting continuously our body, when life appears in the body" (Gal. PHP III 1, 1-7). Indeed, he has already mentioned that, just as the body can be healed through the art of medicine, analogously the doctor of the soul must have in-depth knowledge of the science and the

16 Galen admires Aristotle, especially in terms of the logic and method of writing his works, cf. Daremberg (1848: 1). Aristotle places all three faculties of the soul in the heart where he also places the seat of the soul. Galen repeats it in various books of his treatise, sometimes referring only to Aristotle, other times to other philosophers

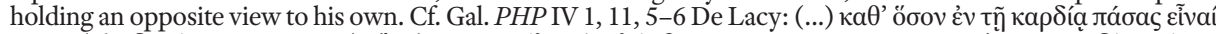

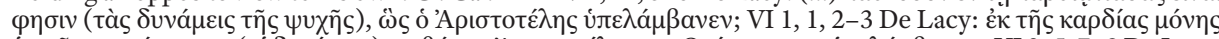

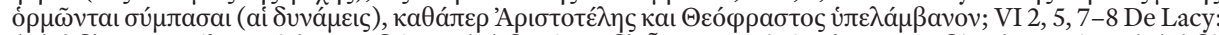

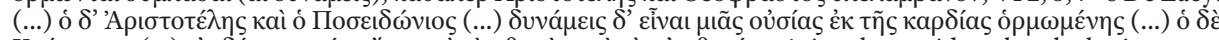

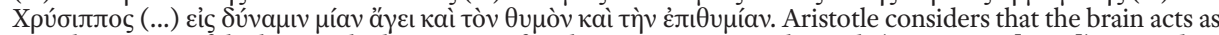
a cooling organ of the heat in the heart area, cf. Gal. UP VIII 3, 620 Helmreich (1907-1909 [1968]). Regarding the approach of the Aristotelian work by Galen, cf. Moraux (1976: 127-146; especially 141-143).

17 Regarding Galen's anatomy studies in Egypt, cf. Baloyannis (2006).

${ }^{18}$ Cf. accordingly, Gal. PHP IX 9, 776, 56, 11 De Lacy.

19 Continuous references to Chrysippus' theory and errors regarding the position of the hegemonikon in the heart appear predominantly in books II-VI of this treatise.

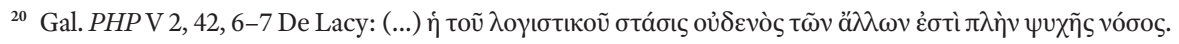

21 Cf. Gal. De morborum causis, 1 (= SVF II 772).

${ }^{22}$ Gal. PHP V 3, 7-8. The question of the concept of symmetry and measure in relation to the human

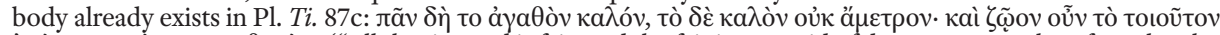

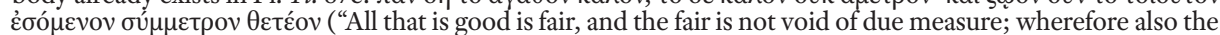

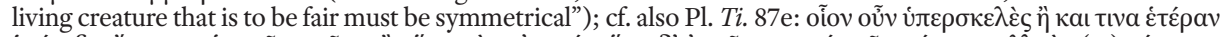

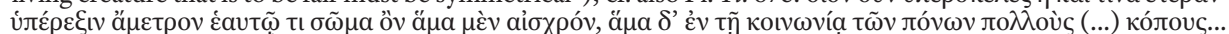
("A body, for example, which is too long in the legs, or otherwise disproportioned owing to some excess, is not only ugly but when joint effort is required, it is also the source of much fatigue and many sprains and falls due to its clumsy motion, whereby it causes itself countless evils"). Cf. Cic. Tusc. IV 13, 28. 


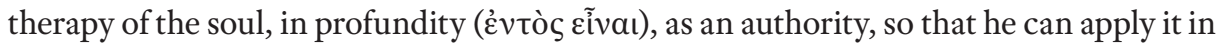
the best way to achieve healing. ${ }^{23}$ The doctor of the soul should know methods of treatment both for the soul and the body in order to achieve the ultimate result: full treat-

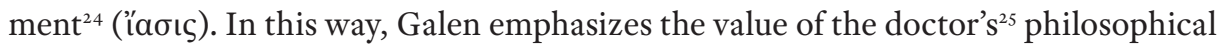
knowledge and stresses the similarity in the treatments of the body and the soul, and the analogy between them. This is an issue on which Chrysippus insists in his treatise On affections (Gal. PHPV 2, 13-25), since the soul and the body are made up of natural elements and, as a result, there is relevance in their treatments (cf. Tieleman 2003: 148). According to Pohlenz, in Chrysippus' times doctors taught that the cause of disease was not due to the external infestation of the patient, but to the disposition of the human body to receiving the external stimulus (cf. Pohlenz 1963: 173). Moreover, while the Stoics tried - as will be addressed later on - to determine ways to treat the affections, Cicero, in this case as a scholar of the Stoics, disagrees with their way of approaching the soul's affections. As he mentions, this is because the Stoics and especially Chrysippus, while analyzing their theories on affections, do not really focus on suggesting ways to avoid them or treat them, but rather on their classification and definition. Thus, in this way they proceed to a categorization, in contrast to the Peripatetics who, as Cicero also asserts, disregard the "thorny" definition issues and pay considerable attention to the soul's relief (Cic. Tusc. IV 5, 9). It is noteworthy that in Book IV of his work Tusculanae Disputationes, Cicero refers meticulously to the Chrysippian treatise On affections ( such an extent that this book can be considered an epitome of the Chrysippian treatise. Indeed, Cicero claims that Chrysippus, particularly in Book III of $\Pi \varepsilon \rho i \pi \alpha \theta \tilde{\omega} v$ possibly suggests solutions with regard to the affections of the soul and their treatment, while Galen seems to make no mention of this issue (Chauvet 1857: 36). According to Cicero, Chrysippus distances himself from the treatment method that his teacher Cleanthes had suggested, providing as a counterpoint of the affections (especially sadness, lype $\bar{e}$ ), the wise man's ataraxia, ${ }^{26}$ which is finally achieved with the provision of advice, meaning that there is nothing bad happening by the provision of relevant guidance. On the other hand, Chrysippus, placing the human being in his/her daily context, believes that the treatment and therapy of sadness must start at the moment of its appearance. According to Chrysippus, the interference of the doctor of the soul (the philosopher), should precede and accustom the potential patient to ataraxia long before the arrival of the affection, which thereby suggests that teaching offers methods to confront it. This is because when sadness appears, the patient, dominated by psychical tension, considers it unavoidable and obligatory. In fact, at the moment of the intensity of passion, there is no room for

\footnotetext{
${ }^{23}$ The extent to which Galen constantly combines the two qualities of the doctor and of the philosopher is impressive; cf. Gal. PHP VI 8, 57 De Lacy.

${ }^{24}$ Gal. PHPV 2, 22-28 (= SVF III 471); V 2, 4 De Lacy. Cf. Tieleman (2003: 147).

${ }^{25}$ Here Galen follows the Platonic theory as to the twofold capacity of the physician: Cf. Pl. $R$. V 454d:

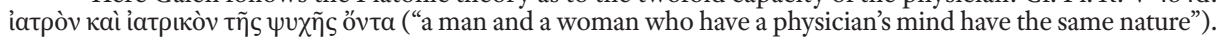

${ }^{26}$ Cf. Cic. Tusc. III 31, 76 ; III 32, 77 (= SVF I 576, 577).
} 
advice or prohibitions. Therefore, despite the objective difficulties existing in this specific theory of Chrysippus, it is ipso facto a crucial part of his philosophy. ${ }^{27}$ The solution recommended by this philosopher is to "solidify" our judgment early on. Posidonius of

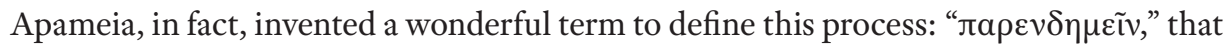
is, to live in misery beforehand so that it will not upset us when it comes. ${ }^{28}$ The affection comes from the individual him/herself in the same way, as a reasonable action. In other words, it is wrong to seek an external factor that our self must conquer as an external intermediary. The "enemy" is within us, and is the expression and the result of what we really are. As to our moral life, we are not just spectators of a fight between two principles ( $\lambda$ ó $\gamma \circ \varsigma$ and $\varepsilon \xi \xi \omega-\lambda o ́ \gamma o \varsigma)$; we ourselves are called upon to transform our passions, to change their direction. According to Chrysippus, an affection is created "not if someone behaves incorrectly, having ignored something which is in accordance to reasoning," but when this impulse is undisciplined by reasoning (Gal. PHPV 4, 12-5, 4). Consequently, our inner morality, that is, our moral consciousness, must always be ready to face any type of affection (cf. Bréhier 1971: 258). In the same context, Cicero, when referring to sadness, stresses that its appearance is vain and useless because it does not derive from nature but from judgment, in other words from opinion, since it is caused by man himself, who considers it necessary (Cic. Tusc. III 33, 81). The Stoics define pathos as a movement of the soul without reason, as unnatural, or as an urge which is in excess ${ }^{29}$ (meaning that it exists once again outside the natural context, as $\pi \lambda \varepsilon \dot{c} v$, a surplus of urge, which is against nature since in nature what dominates is the $\mu \varepsilon \varepsilon^{\tau} \rho{ }^{\prime} v$ and there is no room for anything without purpose). ${ }^{30}$ According to Cicero, this excess psychical urge which creates affection should be considered a "disdain" of reasoning. ${ }^{31}$ The Stoics describe seventy-six additional affections which upset the soul of those uninitiated to Stoicism and which are observed only by the permeating and critical eyes of a Stoic. ${ }^{32}$ That is why Cicero

${ }^{27}$ Cf. Cic. Tusc., in: (Schuhl 1962: 353, n. 2 [V. Goldschmidt]).

${ }^{28}$ Gal. PHP IV 6, 44-7, 5 De Lacy. Cf. also Pigeaud (2006b: 277).

${ }^{29}$ Andronic.Rhod. De Passionibus, 1 (p. 11 Kreuttner (1885) = SVF III 391).

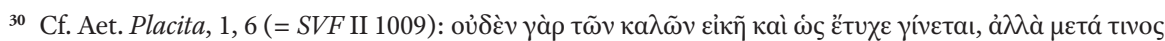

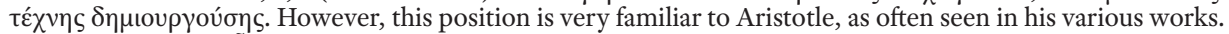

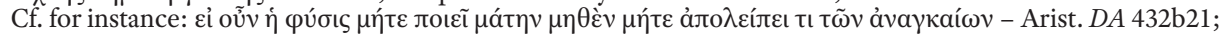

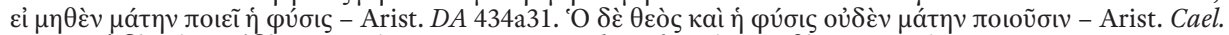

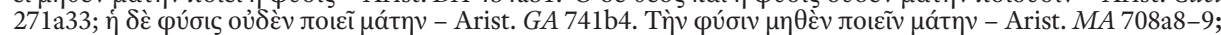

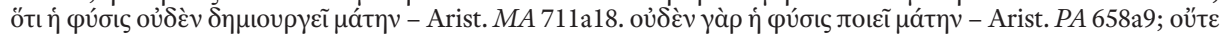

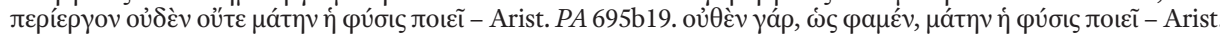

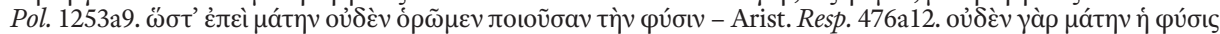
غ̇ंग́ं $\sigma \varepsilon v$ - Arist. Fr. 230, 6 Rose. The same view is adopted by Galen, who repeatedly mentions the technique of perfection and the measure of nature, influenced by Aristotle but perhaps also by the Stoics. Suffice it to refer to

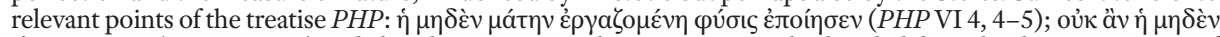

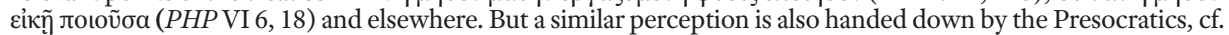

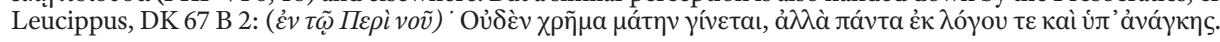

${ }^{31}$ Cf. Cic. Tusc. IV 14, 32. Cf. also Cic. N. D. II 82, where Cicero describes nature to emphasize the perfection and moderation that prevails in it and points out that we see this when we look at a tree or an animal, where nothing is left to chance but through them, it seems that order and art prevail everywhere.

${ }^{32}$ Cf. SVF III 394-414. According to the Stoics, there are four general passions: sadness, fear, desire, pleasure (cf. Andronic. Rhod. De passionibus, 1 [p. 11 Kreuttner (1885) = SVF III 391]). Cf. Daraki (1989: 79-92, espe- 
emphasizes, as mentioned before, that the Stoics were most likely concerned with the classification and definition of the affections, rather than the attempt to find solutions for their eradication, as the Peripatetics did.

That the Peripatetics sought solutions in order to avoid psychical affections is proved by the fact that Theophrastus, according to the list of his works given by Diogenes Laertius, ${ }^{33}$ was the first philosopher to write a treatise entitled On Melancholy. The melancholic human being ${ }^{34}$ is indeed the subject of the text Problems $\mathrm{XXX}_{13}^{35}$ in the Aristotelian corpus, which in general is regarded as pseudo-Aristotelian. This issue, however, will be elaborated on in the second part of the present work.

Galen mentions that the soul, according to the Stoics, is a kind of pneuma, just as nature itself is a pneuma too; however, while nature's pneuma is wetter and colder, the soul's pneuma is drier and warmer, with its creation arising from the symmetrical condition of windy and fiery matter. ${ }^{36}$ The issue of the composition of the soul seems to have already been especially attractive to earlier philosophers; here it will suffice to refer to Heraclitus, who believed that the soul is the effect of exhalations, ${ }^{37}$ and in whose fragments it is observed that at times the dry element dominates, while at other times the wet element does. Hippocrates believed, according to Aristotle, ${ }^{38}$ that diseases come from the airs ( $\varphi \tilde{v} \sigma a \mathrm{l})$ which are caused due to the excessive consumption of foods by the human being, which rush into the human organism and which, with their strength, exhaust its inner heat. Whenever the dry element dominates, because these souls are close to the fire ( $\pi \tilde{v} \rho)$ - the fundamental cosmic principle, they are the perfect ones. On the other hand, if the wet element dominates, the soul is diseased and prone to pleasures and passions. ${ }^{39}$ The healthy soul is fiery. Chrysippus regards the perfect combination

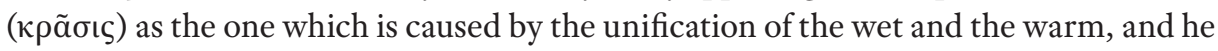

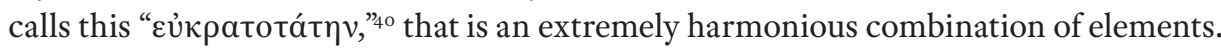
According to the Anonymous author of the Scholia in Hermogenes, Galen considers the

cially 79): "If we really want to understand the astonishing Stoic aphorism: 'passion is no different from reason', the most valuable aid is the description of the seventy-six passions under the prism of the Athenian Stoics."

${ }^{33}$ Cf. D.L. V 23, 14 Hicks (1958).

${ }^{34}$ Cf. the catalogue of Aristotle's works in D.L. V 23, 14, where Diogenes Laertius mentions that he wrote a treatise entitled On Problems $\alpha^{\prime}$.

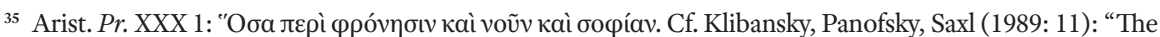
various manifestations of melancholy are clearly presented in Problem XXX 1 the extremely important essay on the history of this concept and its relation to the spirit" (transl. by the author). Cf. Mirhady (2011, especially 274-275).

${ }^{36}$ Gal. Quod animi mores corporis temperamenta sequantur, I 346 (SVF II 787). Cf. also IV 26-27, 15-18 Bazou (2011).

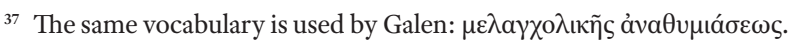

38 Anon. Lond. V 35 (Thivel 1965: 267).

39 DK 22 B 118 and 117. The same perception prevails in Aristotle ( $D A 405 \mathrm{~b} 26)$ but also in the Stoics, as in Zeno and Cleanthes.

${ }^{40}$ Gal. De temperamentis, 1 (I 523 Kühn = SVF II 770). 
soul to be the specific combination of elements, from which the human being is created. ${ }^{41}$ Apart from this analogy, there is also the analogy of the parts of the human body to the cosmic bodies: "On the contrary, the rational principle is in control; and that is why the stars revolve fixed like "radiant eyes" in the countenance of the universe, the sun in the heart's capacity transmits and disperses out of himself heat and light as it were blood and breath, while earth and sea 'naturally' serve the cosmos." ${ }^{\text {"2 }}$

Galen proceeds to outline many similar correlations which clarify his belief in the tripartite separation of the soul. The majority of these are drawn from his Platonic education (cf. Singer 2013: 205-217), with particularly apt examples from the Sophist which contrast health, which he associates with the good physical condition of the body, with illness, which he describes as destruction ( $\varphi \theta 0 \rho a ́)$ and, consequently, an abnormal situation. In essence, these two bodily conditions resemble a city which is tormented by civil war. ${ }^{43}$ Galen considers that this specific correlation clearly represents the difference between the two physical conditions of the body. Health is compared to peace among the citizens, while illness inflicts the body, just as if a civil war has broken out: "the cities are ill within them, just as those who despite being relatives by nature, they reach a point of fighting each other." ${ }^{24}$ This is the specific correlation with which Galen lucidly defines the two aforementioned conditions..$^{45}$ Just as it happens during a civil war, where a specific group of people have an overwhelming desire to impose their decisions and rules on the mass of citizens, by the use of any means possible, and then the instincts dominate over reasoning; the same happens with the attempt to impose the unreasonable force of the

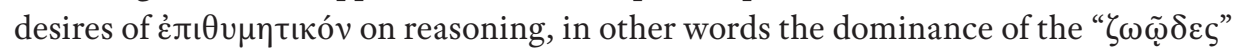
aspect of the soul on the reasonable part, its " $\theta \varepsilon$ ĩov" aspect (Gal. PHPV 3, 19-27). Galen levels criticism at Chrysippus, not only with regard to the trilateral aspect of the soul which he obviously supports, as mentioned earlier, but also with regard to Chrysippus' inconsistency concerning the unilateral aspect of the soul which at times falls ill, as

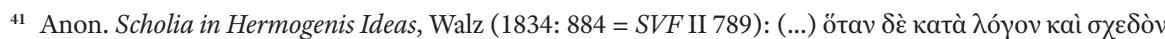

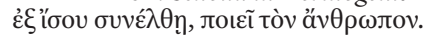

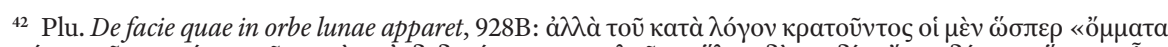

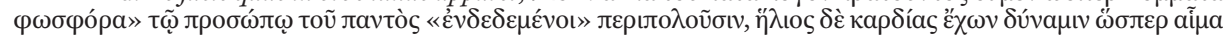

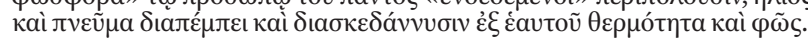

${ }^{43} \mathrm{Pl}$. Ti. 82a. The disease is also described here as "stasis," i.e. illegal insurrection, disorder, cf. Pl. R. 444b and $S p h .228 \mathrm{a}-\mathrm{b}$. "Plato also adopts political metaphors to describe health and disease, a tradition started by Alcmaeon, who described health as the 'equilibrium' of opposing forces”. Cf. also Thivel (1695: 267), where it is mentioned that, according to Aristotle, Hippocrates held that when the foods that enter the body are either excessive or of a different nature or even too spicy, then they end up in conflict (attitudes) within the body. This results in the formation of surpluses, which cause "phases", which in turn cause diseases.

${ }^{44}$ Gal. PHPV 2, 34-43 De Lacy. Cf. Pl. Ti. 82a: "Because when an element is formed or displaced contrary to its nature, it causes heat where there was cold before, conversion of dry into liquid, of light into heavy and vice versa, and any other change. However, we claim that only what they come to and from which they leave with the same ingredients, always in the same way and proportion, remains unchanged, safe and healthy".

${ }^{45} \mathrm{Cf}$. Pl. Ti. 82a. Plato approaches the phenomenon of disease as a natural philosopher and not as a doctor. This is the only conclusion of the detailed discussion of the subject by Miller (1962). Disease is any reversal of the normal balance of inputs and outputs of the four elements, a balance that constitutes health. It is possible that Plato was influenced by the medical theories of Alcamaeon and Philistion, but also by Diocles, as argued by Cornford (1937: 332-334). 
happens with the soul of the foul, and at other times is in health, as happens with the soul of the sage. Galen asserts that Chrysippus at times even contradicts himself on this matter.

However, what happens when the human being is not in control of him/herself? What happens when the human being drifts away or is enslaved by his/her passions?

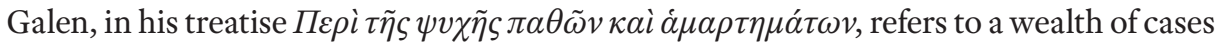
of disgraceful punishment of some slaves when masters are in a state of mania. ${ }^{46}$ Mania, according to Galen, makes the soul appear like boiling water ${ }^{47}$ and the mania which arises due to this state is an affection which strives to find an outlet so that suppressed feelings can be loosened. ${ }^{48}$ It is obvious that, in this case, the slave is transformed into a means of venting feelings while the master is transformed into a castigator. The aim is a form of treatment from pathos, that is, the restoration of the patient's health. This comes gradually, after the restitution of reasoning and its domination over the affections. This interactive relationship between the master and the victim also defines the relationship between reason and affection. The slave is inflicted with punishment by his castigator, who has already inflicted punishment upon himself. In other words, the slave suffers from the sufferer, who finds himself in a state of psychological submission to his instincts. The anecdote provided by Diogenes Laertius describes exactly the above behavior: When Zeno, the Stoic philosopher, once saw a slave who was bruised talking to his master, who was an acquaintance of Zeno, the latter remarked that he saw on the slave traces of the master's own anger (D.L. V 23). Galen, who was definitely aware of such reactions, stresses that people's decisions must be made only when their psychological

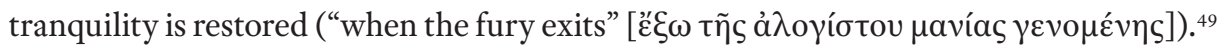

According to Galen, anything that is exaggerated simply cannot be nice. The phenomenology of the psychical functions reveals, for instance, the ugliness of the soul when it is in a state of rage: "(the sufferers) do anything: hitting with their feet and hands, ripping clothes, looking around them with mania, to such a degree that, as I said, fight with the doors, the stones and the keys, breaking some, biting others and hitting them. ${ }^{\text {so }}$ In the same treatise Galen asserts that we must control the affections of our soul through logos instead of through lashing, ${ }^{51}$ and stresses that rage is nothing less than madness. Galen

${ }^{46}$ Gal. De propiorum animi cuiuslibet affectuum dignotione et curatione, \$\$5-6 De Boer (1937).

47 This analogy found as a rule in the Aristotelian Pr. XXX 1, 954a15, which describes the ecstatic behavior of man, that is, when his body is under the influence of fiery bile, which carries him out of himself; similarly with boiling water, which becomes warmer because of the flame, as it happens with the stone and the iron. But the Stoics use the same analogy when, using the example of the properties of stone and iron, they describe the ways in which the disease is cured; cf. Olymp. in Alc. 54 (= SVF III 489).

${ }^{48} \mathrm{Gal}$. De propiorum animi cuiuslibet affectuum dignotione et curatione, $\$ 22$.

${ }^{49}$ Ibidem.

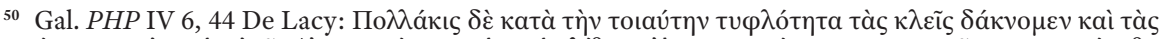

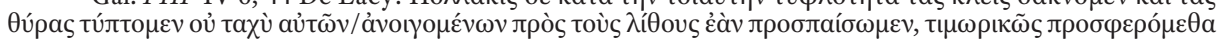

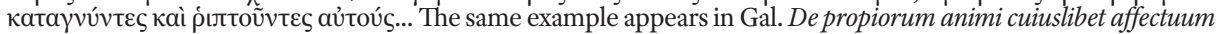
dignotione et curatione, $\$ 22$.

${ }^{51}$ Cf. Gal. De propiorum animi cuiuslibet affectuum dignotione et curatione, $\$ 21$. 
emphasizes that Chrysippus places the affections within the heart, where he believes that the 'leading' capacity of the soul (the hegemonikon) resides (Gal. PHP II 19-31).

The Stoic philosopher does not have the medical knowledge of Galen, ${ }^{52}$ and as a result his views fall short of having a scientific character as regards the functions of the brain and the heart, while Galen considers that the 'leading' faculties reside in the brain. According to Chrysippus, everything develops in the hegemonikon, everything is the result of the messages that the other parts of the soul transmit to it for processing (Gal. PHP III 1, 9-18). Despite the above, it should be mentioned that there are testimonies from Galen which suggest that Chrysippus, in the first book of his treatise On the soul, and following the Platonic division of the soul, placed the reasoning part in the head (Gal. PHP IV 1, 5-7), the affect in the heart, and the desire in the navel. Similar information is provided concerning Cleanthes, since, according to Galen, Poseidonius, in his treatise On affections, proved that a human being is dominated by three (psychical) faculties:

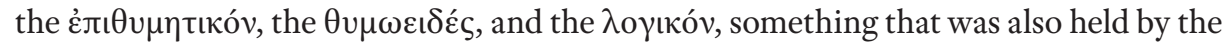
philosopher from Assos..$^{53}$

How is affection defined? What is its essence, what is its relationship to the pain and the illness? When does man suffer in his soul and how does he react to external stimuli when these target and impinge on the hegemonikon of the soul? According to the Stoics, there are four types of affections: sadness, fear, desire and sexual pleasure (D.L. VII 110-111). Zeno, as has already been mentioned, was of the view that affection is an irrational and unnatural motion of the soul or an excessive impulse, ${ }^{54}$ and, in order to describe the sudden speed of this motion, he compared it to the agile movement of a bird (лтoía $\psi \cup \chi \tilde{\eta} \varsigma$ ). ${ }^{55}$ This impulse generates a counteractive turn (perversion) in the mind, ${ }^{56}$ and through the disorder that is caused the affections can grow in the soul (D.L. VII 110), because in this case, in contrast to the stability that reason assures, there is confusion and instability. ${ }^{57}$ Galen suggests that Chrysippus considers the cause of the perversion to be twofold, and this is due just as much to the interaction with many people as to the nature of things (Gal. PHP V, 462 14-15). In any case, it is known that Chrysippus paid great attention to the interaction of children from a very young age with highly proficient educators, and further still with fully capable caregivers. Chrysippus himself, obviously affected by the Platonic philosophy regarding the education of the young, claimed that

52 Galen, as an authority in medicine, criticizes Chrysippus, pointing out that the philosopher repeatedly uses non-scientific evidence such as examples from myths, women and poets, cf. Gal. PHP VI 8, 77-79 De Lacy.

${ }^{53}$ Gal. PHP VIII 1, 14-15 (= SVF I 571).

${ }^{54}$ D.L. VII 110 (= SVF I 205). Cf. also Plu. De virtute morali, 3, 441C (= SVF I 202).

55 Stob. Ecl. II 7, 1 (= SVF I 206).

${ }^{56}$ Gal. PHPV 5, 14, where according to Chrysippus, the cause of the perversion is twofold.

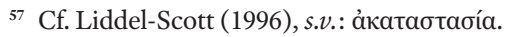


the damage inflicted on children's souls by incapable and badly-mannered caregivers increases gradually, so that in the end they leave indelible marks on their souls..$^{58}$

Reason does not exist in a separate place, nor does it monitor the affections in such a way so as not to allow them to move on after a specific limit. Instead, reason itself changes into affection and this is why it is impossible for someone to call upon this useful force (reason) for assistance, since it has already been betrayed and rendered absolutely powerless (Sen. De ira, I 8, 2). The human being who possesses such a soul is completely removed from reason and consequently is transformed into a psychological patient (Cic.

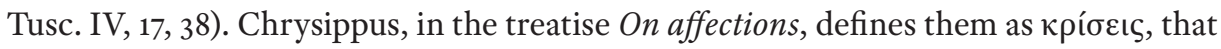
is, as opinions of reason, and compares them to illnesses of the body in a feverish state, which is suffering from the serious illnesses ${ }^{59}$ that Zeno had already compared to arthritis, rheumatism and diarrhea. He held that it was an inflammation that definitely required treatment (cf. D.L. VII 115). Cicero argued that the term affections ( $\pi a ́ \theta \eta)$, which the Greek people used, would be best translated into Latin as perturbations (perturbationes), rather than as illnesses (malum) (Cic. Tusc. IV 5, 10-11), since, as he believed, the affections are in motion and this motion is what causes the illnesses. Could it be, however, that what is at issue here is not the "motion" of affections, but the movement of the soul which results as a consequence of the affection and, therefore, we should use the term perturbation to refer to this specific motion, which is a secondary reaction of the soul, the movement which results from the arrival of the affection? ${ }^{60}$ Melancholy should be included among the psychical and physical motion reactions, since, according to Galen, it consists of a psychical and physical affection; reference will be made to the influence of relevant pre-existing theories on his views.

\section{b) Melancholy, as a psychical and physical affection}

Melancholy, considered both as an affection that appertains to insanity, an emotional condition characterized by sadness and fear, and as an illness, occupies a considerable portion of the medical treatises written by the ancient Greek and the Arabian doctors of the 9 th and 1oth century.

Plato, for instance, ${ }^{61}$ in the Republic uses the adjective "melancholic" together with the adjectives "exhilarating" and "erotic" to characterize the tyrannical individual, whose

${ }^{58}$ Quint. Inst. I 1, 4 De Lacy (= SVF III 734) and I 10, 32 (= SVF III 735).

59 Gal. PHP V 2, 4 De Lacy. Cf. also, D.L. VII 115.

${ }^{60}$ This process involves the function of the sens, the imagination on the hegemonic part of the soul and its gradual forms. Cf. also relevant excerpts: SVF II 71-80. Cf. Mates (1953); Kneale, Kneale (1962); Mignucci (1972); Frede (1974) (scattered throughout the article); Gourinat (2017: 121-129).

${ }^{61}$ We mention here only examples from the Platonic work that are indicative in terms of meaning. 
flaws were created either by nature or by nurturing, or both ${ }^{62}$, and due to this he borders on madness. This concerns the corrupted character, who is focused solely on the satisfaction of his instincts, by which he is constantly enticed. Plato also likens melancholy to madness in the Phaedrus: ${ }^{\tau} \Omega \mu \mathrm{o} \chi \theta \eta \rho \varepsilon$, $\mu \varepsilon \lambda \alpha \gamma \chi 0 \lambda \tilde{\alpha} \varsigma$ (Phdr. 268e - "poor man you are out of your mind"). We can notice that in the above cases the relevant defining terms focus on emphasizing the deviation from the reasoning.

In any case, the face of the melancholic whose soul changed in affect and behavior, under the influence of an external factor, always constituted the point where medicine met with philosophy. Indeed, the questions that arise through examining the phenomenon of melancholy, such as the extent to which there is interaction between body and soul and vice versa, cross these two sciences. In fact, there is intense discussion on the location of the hegemonikon and theories are posited by both sides. A special place in the investigation of this affection is held by the studies of the doctors Rufus of Ephesus and then Galen; the latter was a student of the former and considered his teacher's treatise to be perfect. ${ }^{63}$ This text was drawn on by all subsequent doctors until the Renaissance (Klibansky, Panofsky, Saxl, 1989: 99 ff.). The case of the melancholic individual and his behavior had strongly concerned the ancient philosophers, as previously mentioned, and according to the available testimonies Aristotle and Theophrastus had already examined this subject. The Stoics finally held that this psychical condition had such an influence that even the sage (virtuous) lost his virtue when under its sway. ${ }^{64}$

It was already known to the Pythagoreans that the four seasons of the year are connected to the four ages of the human being. This theory resulted in establishing a relationship among the four humors (blood, phlegm, yellow bile and black bile), and the real health of the human being was held to depend entirely on the correct blending of these humors in the body. Moreover, while these humors were regarded as causes of illness or susceptibility to it, depending on their balance in the body, they were simultaneously connected to the cosmic elements (cold, hot, dry, wet) which, in terms of health or illness, are neutral. Medicine, however, always relied above all on the human being and on his/her dialogue with the world, and tried to find the connective link. Therefore, the individual who is always healthy is one in whose body the four humors join and balance; this individual is consequently the ideally and exclusively healthy person, who naturally belongs to an ideal and the rarest category of reality. According to Galen, every human

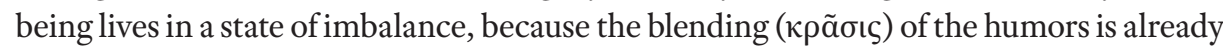
the beginning of a painful "disorder," since in every human being there is a prevalence, I 206).

${ }^{62}$ Pl. R. 573c. Here we suggest that Chrysippus follows Plato's point of view; cf. Stob. Ecl. II 7, 1 (= SVF

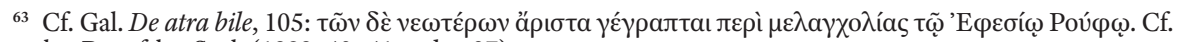
Klibansky, Panofsky, Saxl, (1989: 40-41 and n. 27).

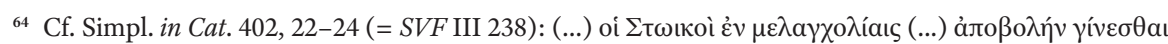

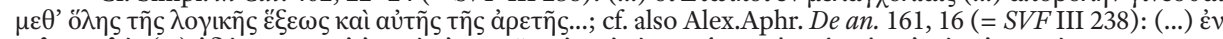

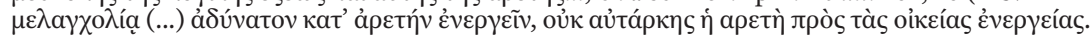




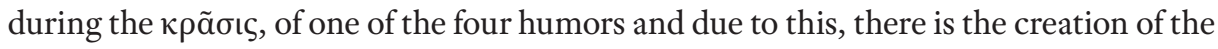
'Ítov of each human being, that is, of his/her idiosyncrasy (Klibansky, Panofsky, Saxl, 1989: 41 and n. 27). Within this context, the tradition that related an illness to each different "dosage" of a specific humor, is gradually revoked, owing to the acceptance of the theory that every organism has a specific composition (Moraux 1981: 90-93). Indeed, not only the one in whose body there is absolute order is healthy, but also the one in whose body one of the four humors prevails, and, despite that, it is possible to be in good health even if the level of his/her health is not exceptional. The blood holds the most privileged position among the four humors, though, gradually, the types that arise from the surplus of the rest of the humors create the relevant characters (evil, phlegmatic, melancholic, hematogenic) or rather physiognomic types, according to Singer, ${ }^{65}$ which depend on the prevalence of one of the four humors in each human being. ${ }^{66}$ Melancholy was gradually distinguished from the other крá $\sigma \varepsilon ı \varsigma$ and was defined as a condition between illness and predisposition, between illness and character. ${ }^{67}$ Within this context Galen writes: "the dark color of the black bile creates fear and clouds reasoning." ${ }^{8}$ This is related to the determination that Hippocrates had already expressed in his Aphorisms 6.23, as follows: "If fear and sadness last for long, this is an indication of melancholy." Since then, this term has been connected with psychopathology and persists today, very often to define depression.

In the expansion and development of the issue of melancholy as an illness, and also as an intellectual superiority in philosophy, a vital role was played by the Aristotelian text of Problems XXX 1, in the fourth century BC, which according to tradition is ascribed to Aristoteles, despite doubts about its patronage. However, Cicero (Tusc., 1, 33), Seneca (Tranquil. 17, 10) and Plutarch $(\text { Lys. 2, 5) })^{69}$ explicitly mention that it is a text of Aristotle, ${ }^{70}$

${ }^{65}$ But character, according to Galen, is a condition of the natural environment in addition to the family, as seen before in Plato and Chrysippus. Cf. Gal. PHP V 5, 464, 23-24 Kühn, where he states that the passive movements of the soul follow the state of the body, which is significantly altered by the wine of the environment. Cf. Bazou (2011; especially, \$ XI, 86-87). The same view is found in Cic. Fat. IV 7, where Cicero refers to the atmosphere of Athens, which creates the subtlety of the spirit of the Athenians. But also in the Platonic Timaeus (Ti. $24 \mathrm{c}-\mathrm{d}$ ) the old man refers to the virtues of the Athenian character, which thrive due to the appropriate climate.

${ }^{66}$ Singer (2013: 29 and. n. 4). Be that as it may, it was Galen's version that had the greatest impact. It should be emphasized, however, that the relative theory of characters - and especially the melancholy - related to "black bile" and so often found in the Western literary tradition, is medieval and does not belong to Galen. When Galen uses such terms, he refers either to specific bodily substances or diseases, or to physiognomic types, and not to characters in the broader sense.

${ }^{67}$ The theory of the four humors/characters, defining physical and mental characteristics, was developed and during the 2nd c. A.D. Cf. Klibansky, Panofsky, Saxl (1989: 44 and note 39).

${ }^{68}$ Gal. De locis affectis, III 10. Klibansky (Klibansky, Panofsky, Saxl 1989: 77) finds many similarities to Aristotelian terminology, but it would be dangerous to attribute it to Aristotle without reservation. As already mentioned, the fact that Aristotle, according to Diogenes Laertius, wrote a treatise entitled Problems and that Theophrastus, always according to him, wrote a treatise On Melancholy, and Characters, may allow us to assume that this is a work written in the Lyceum by a student of Aristotle and at time not far from when Aristotle taught at the School. It is definitely part of the Peripatetic/Aristotelian tradition, in the Aristotelian corpus.

${ }^{69}$ Cf. D.L. V 23, where he mentions that Aristotle wrote the treatise On Problems.

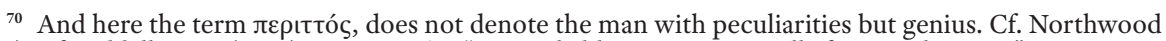
(1998). Cf. Liddell-Scott (1996), s.v. лepıтtós: "a remarkable person, especially for great learning". He is excep- 
and a considerable number of extracts are drawn from it by the doctors Rufus of Ephe-

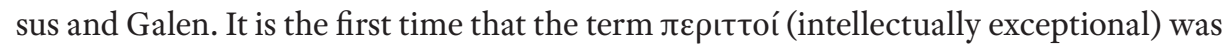
used to describe unique personalities, in which however, melancholy can dwell (Singer 2018: 410-411). At the same time along with this characterization, the tradition is fractured since hitherto it associated melancholy with the passion of madness or mania. ${ }^{71}$ Initially, Aristotle asks himself why the $\pi \varepsilon \rho \iota \tau$ เó, such as philosophers, politicians, poets and artists, are melancholic: "why is it that all men who are outstanding in philosophy or politics or poetry or the arts are melancholic...” (Pr. 953a); and some heroes are equally melancholic: Heracles, Ajax, Bellerophon, but also Lysander, who, before dying is full of ulcers, just like Heracles. Once more, here it is obvious that there is a relationship

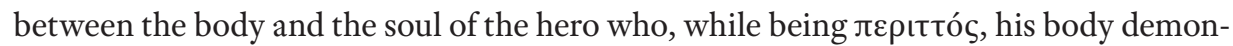
strates a painful illness, leading him to melancholic suicide. The explanation that is offered hereafter, focuses on the two elements of which the black bile consists: the dry and the cold; $7^{72}$ during their mixture and during the symptomatic domination of one over the other, thereby causing physical and psychical reactions in the melancholic human being (Pr. 954a). According to the Aristotelian text, it is possible for black bile to lose or gain more temperature than normal. This bipolarity also creates two types of symptoms: when it is especially low in temperature, black bile causes sedation, paralysis, dysthymia, fears; and when it is higher, it causes a euthymic mood with songs, ecstasies, the development of ulcers (as in the case of Heracles) and such like (Pr. 954a23, 25). In this way, the melancholic human being is presented by the ancient authors as living with a cyclothymic bipolar condition, from incontinent and precocious to depressive, in the meaning that is assigned to this term by modern psychopathology, since it seems that this man has the predilection to follow his impulses. ${ }^{73}$

First and foremost, however, Problem XXX 1 introduces the philosophical and psychological notion of genius, which denotes the лєрıттоí. These extraordinary personalities are capable of withstanding black bile the most; they can retain it in balance

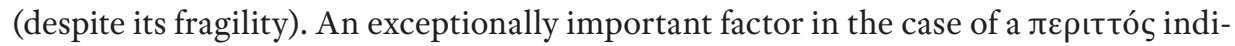
vidual is the behavior of the weather in a special situation. It all depends on the kairotic moment, the conditions and the state in which black bile exists in the human organism. If, for instance the announcement of an event generates fear and this fear in turn freezes the individual, who at that moment is dominated by cold melancholy, then the same individual behaves as a coward, since black bile has opened the path to cowardice (غ่à $v$

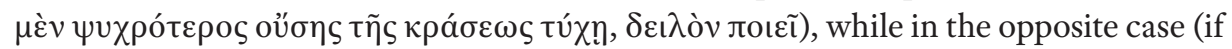
the bile is hot), then the human being behaves with moderation and remains apathetic

tional, excels in knowledge, he is a rare one and admirable person.

${ }^{71}$ As seen in the Platonic examples above.

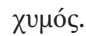

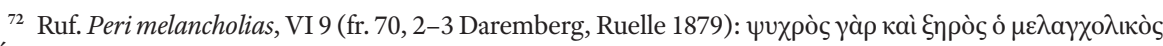

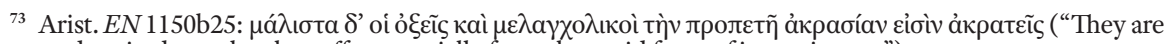
intense and excited people who suffer especially from the rapid form of incontinence"). 


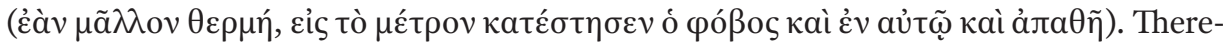
fore, a melancholic individual is a kairotic person. ${ }^{74}$ This is the exact point where, according to Aristotle, the distinction between the pathological conditions of melancholy and a refined type of genius appears. During the procedure of humor mixing, only a moment is required for it to emerge; and here Aristotle describes Empedocles, Socrates and Plato

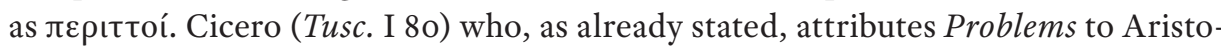
tle, translates the adjective "лєрıтто'” as "ingeniosi" marking the beginning of the term "genius," that is intellectual excellence (Grafton, Most, Settis 2010: 580-581).

In Problem XXX 1, there is a simile which compares the different expressions of melancholy as a result of wine consumption. However, during the 6th century Heraclitus had already emphasized the catalytic influence of wine, which has the potential to moisten the soul to such an extent that the adult loses not only his reasoning but also his memory and his bodily functions, being transformed into prey in the grip of the fools. ${ }^{75}$ Aristotle, in turn, compares the state of melancholy deriving from nature (since nature itself has created the humors of the human body through a balanced or disturbed mixture) with the quantity of wine existing in the organism (especially red wine, which is considered to contain more air) since the transformation of black bile affects human behavior in a similar way to the excessive consumption of wine. ${ }^{76} \mathrm{It}$ is about the wine of the soul, since, just as the wine that is consumed influences every character and changes it, similarly, black bile affects every organism. According to the Aristotelian text, the large quantity of wine in the organism results in the creation of many types of melancholic people with various behaviors. ${ }^{77}$ Indeed, Aristotle clarifies that the one who drinks a specific quantity of wine changes somewhat and reacts in a unique way under its influence; correspondingly, the one who has this character by nature has similar reactions. ${ }^{78}$ According to the text, it so happens that, just like drunk people, the melancholic become extrovert, rambling, sensitive, explosive, aggressive, empathetic, and even suicidal. The

${ }^{74}$ Pigeaud (2006a: 23). Cf. Moutsopoulos (1991: 73-76). Here we refer to the sculptural representation of Kairos by Lysippus, which gives exactly this meaning of the instantaneous reaction. Lysippus, according to tradition, had placed this real bronze, allegorical statue outside his house. The epigram of Poseidippus is well known and refers to the allegorical form of Lysippus' work. $(A G 16,275)$. Today, part of the relief depiction of the Kairos is kept in the repository of the Acropolis Museum.

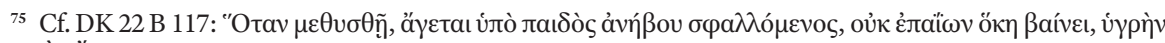

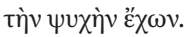

${ }^{76}$ Cf. Stob. Flor. IV 37, where reference is also made to Pythagoras for the effect of food and wine on the

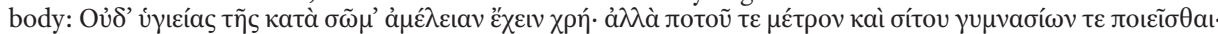

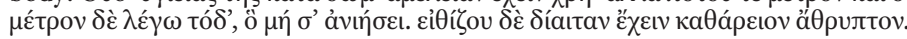

77 Arist. Pr. 953a: The cause of this may be understood if we first take an example from the effect of wine which if taken in large quantities appears to produce such qualities attributed to the atrabilious, inducing, as it is drunk, many different characteristics, making men instantly irritable, benevolent, compassionate, or reckless; whereas no such results are produced by honey, milk, water or anything similar. One can easily see that wine has a variety of effects by observing how it gradually (953b) changes those who drink it.

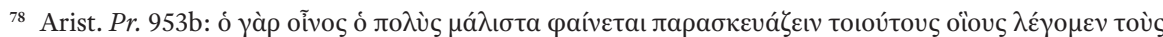

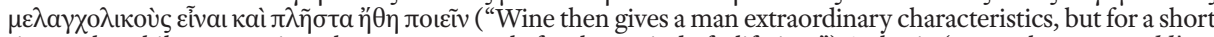
time only, while nature gives them permanently for the period of a lifetime”). Zaharia (2003; ch. 3: Le Problème XXX 1). 
cold and the warm are active elements while the dry and the wet are passive. The characteristic of black bile when compared to the other humors is that it has the potential to change suddenly from a state of natural coldness to a state of excessive warmth. In this way, and due to the fluctuations of warmth and coldness, the individual in whose organism black bile dominates, and depending on his situation in a kairotic moment (that is at times hyperthermic and at other times completely hypothermic), demonstrates the reactions that depend on black bile (from pathological to physiological). If for instance, there is hypersecretion of black bile in the organism, this, combined with the type of food that has been consumed, momentarily alters the mood, with all the reactions that were mentioned earlier, but not the character. Wine and heavy food have the potential to alter all of our moods. However, the melancholic individual, by his very nature, will suffer much more, since within his body there is the type and quality of black bile that has already defined him as melancholic. Consequently, the Aristotelian text concludes that the creation of the $\pi \varepsilon \rho \iota \tau$ tó

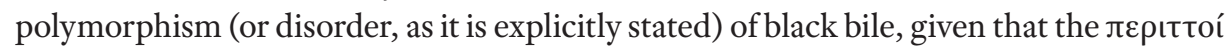

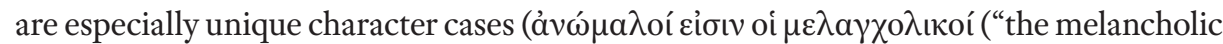
suffer ups and downs”) - Pr. 955a) due to the fluctuations of black bile, from exceedingly warm to especially cold. In fact, since black bile forms an individual's character

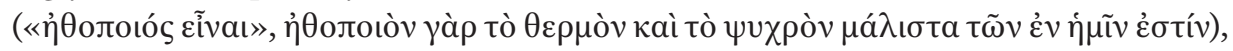
it is absolutely identical to the properties of wine when it enters our body in various quantities and thus shapes our character, momentarily or continuously. Indeed, this happens because wine and black bile are gaseous; and while it so happens that a unique condition is caused (disorder), it sometimes creates a good mixture, ${ }^{79}$ so that the $\pi \varepsilon \rho \iota \tau$ со can sometimes arise from the entirety of melancholic individuals, either as a learned behavior as in the case of wine, or by nature. ${ }^{80}$

According to the Stoics, virtue, or absolute wisdom, marks the purpose ( $\tau \varepsilon \dot{\lambda}$ os) of the life of the Stoic sage. The cases in which the loss of virtue appears are specific and are due to factors that coincide, as we believe, with the factors of the Aristotelian text, since if the sage falls into lethargy, into melancholy, if his mind is temporarily clouded, if in general he is in such a condition that he cannot do anything according to virtue, then even the virtue that exists within him as a personal achievement becomes dysfunctional. ${ }^{81}$ If this is the situation, it should be accepted that there are cases where wisdom also depends on the bodily condition of the human being, and not only on his/her reasoning. It should, therefore, be accepted that there are important physical factors and that the good health of the body is a precondition for virtuous acts (Pigeaud 2006b: 312). According to Stoic

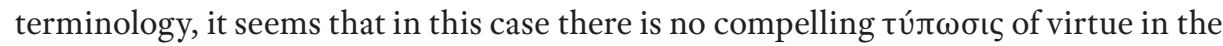

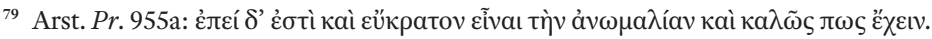

${ }^{80}$ The explanation of the final verse of the text states that since there are many kinds of melancholic people, due to different moods and different circumstances, there is the possibility of euphoria in all and in this case, the emergence of the unnecessary, the genius, potentially exists.

${ }^{81}$ Alex. Aphr., de An. 6, 15 Bruns (= SVF III 239). 
soul, but rather an undefined outline, which, since it is engraved deeply in the soul, it is likely to fade or be altered easily (Pigeaud 1988: 169, and n. 28). The Stoics demonstrate a divergence of views on the issue of the loss of virtue. Cleanthes believes that the acquisition of virtue is eternal, while Chrysippus believes that virtue fails when a human being is in a state of drunkenness or melancholy, ${ }^{82}$ since in both cases the mind is affected by disorder, insanity, diversion from reasoning and from the control of his actions, even if it is all momentary. Moreover, according to Theophrastus, Heraclitus, under the influence of melancholy, does not manage to complete his work, while at various points he even expresses controversial views (D.L. IX 6). The acquisition of virtue does not last forever since it is a volatile value and prone to external factors that influence the life of human beings, in the sense that they, both as personalities and as bodies, are subjected to continuous changes. Consequently, virtue depends on the unique nature of each individual, leading to the possibility of losing virtue at times; and indeed, this happens frequently when it is accompanied by pharmaceutical treatment or when the individual is overwhelmed by lethargy, a headache or melancholy. It is, however, important to note, as Aristotle and the Stoics emphasize, that the loss of virtue does not lead automatically to the emergence of evil (Simpl. in Cat. 237, 25-32). It is simply a disturbance or temporary loss of the wisdom ( $\chi \alpha \lambda \omega \mu \varepsilon \dot{v} \eta \varsigma)$ of the sage, which is in fact a main feature of his deci-

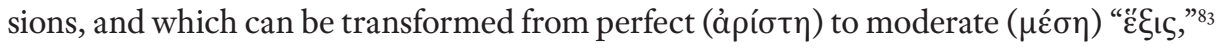
with the accompanying anticipation of its restoration. ${ }^{84}$ The fact that the Stoics refer to the impact of wine on the behaviour of the human being is quite well known; it suffices to recall some characteristic testimonies of Diogenes Laertius, as for example the merry behaviour of the always sullen Zeno after wine drinking and his resourceful reply to the wondering Athenians: "the lupines are also bitter, but when you dip them in wine, they become sweet." ${ }^{85}$ Despite the jesting, however, the Stoics were the philosophers who taught that unpretentious clothing and behaviour are the characteristics of the sage

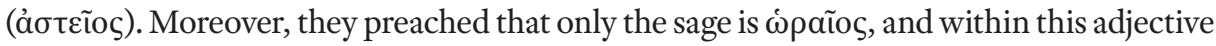
they included their entire teachings, indicating in this way the one who can abstain, the person who does things in moderation in all aspects and expressions, even during festivities; "they will take wine, but not get drunk." He might allow some trace of contained, personal pleasure, like Zeno, who enjoyed drinking flavored wine, but always in a small quantity (D.L. VII 13), but he will not allow himself to be enticed into mania. And if some-

82 D.L. VII 127 (= SVF III 127).

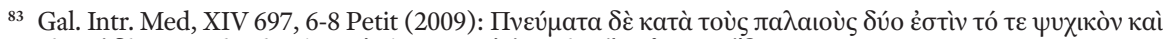

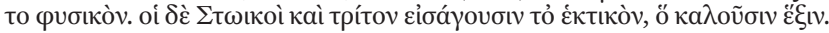
body.

${ }^{84}$ Cf. Pigeaud (2006b: 302). According to Aristotle, the disease could not exist without any change in the

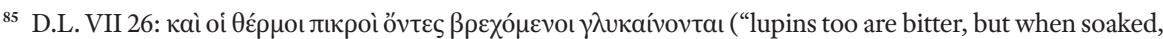
they become sweet"). 
times he becomes melancholic and fantasizes about odd things, this might happen, but it will be foreign to his nature. ${ }^{86}$

Given what was mentioned earlier, it can be observed that among all the philosophers to whom reference has been made hitherto, there is a hidden sense of the middle term dominating, of the Aristotelian mesotes, which seems to represent the rule around which their intellect develops. Even Galen, in his capacity as a doctor, considers that there must be a rule which will impose symmetry and the mixture of humors, just as symmetry defines the art of sculpturing. It goes without saying that the achievement of balance in the mixture of humors is more painstaking since here there are organic elements that are not easily subjected to the rules of Polykleitos or Myron. The doctor, however, when

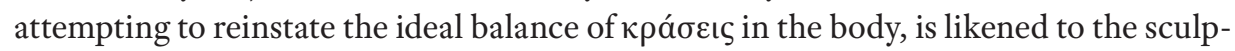
tor; he even possibly replaces him, emerging with this intervention as a rival of nature (even though Galen seems to show his full respect). ${ }^{87}$ Within this context, the doctor of Pergamum seems especially sensitive as to the maintenance of the balance of the humors of the body since he is fully aware of the negative impact of their imbalance. He tends, however, towards reinstating the balance using treatment methods which vary depending on the cases; heating, catharsis, analgesic of the soul, like wine which has relieving properties, when sadness and dysthymia burden the soul, as he states in one of his most

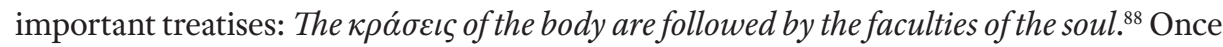
more, in this case, Galen refers to the example of Zeno with the bitter lupines, which become sweet when wet, and advises the daily consumption of wine, which is harmful when consumed in large quantities, but beneficial when consumed with prudence

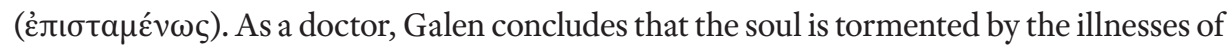
the body, especially when it concerns cases such as melancholy or mania. ${ }^{89}$ What primarily interests him, just as his mentor Rufus of Ephesus, is the written accounts of the symptomatology and the continuous and persistent observation of the patient's behavior, as it can be inferred from the treatise On Melancholy. Galen applies the "scientific method," in combination with experience, and then decides on the suitable pharmaceutical treatment for each patient's case. In this, Galen was extremely successful, which led to the envy and anger of other doctors of his time..$^{\circ}$

In his efforts, Galen finds a supporter in the Stoic Chrysippus, since already in his

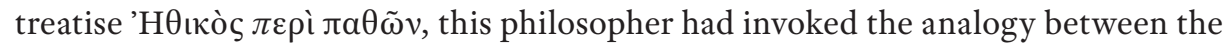

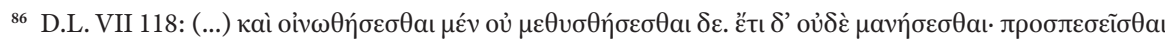

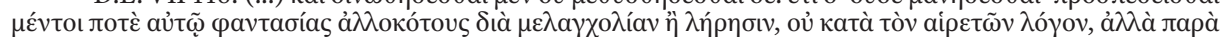

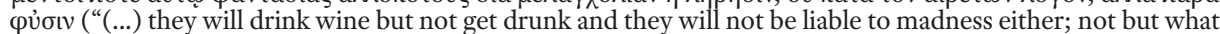
there will at times occur to the good man strange impressions due to melancholy or delirium, ideas not determined by the principle of what is choice worthy but contrary to nature").

${ }^{87}$ Barras, Birchler (1994: 31-32 and n. 14).

${ }^{88}$ Gal. Quod animi mores corporis temperamenta sequantur, III (Bazou 2011: 19, $1 \mathrm{ff}$.).

${ }^{89}$ Ibidem, VIII Bazou (2011: 49, 11-13).

${ }^{90}$ Cf. Gal. De indolentia, $\$ \$ 27-36$ (Boudon-Millot, Jouanna 2010), in which the training of Galen and his superiority over his other contemporary colleagues are shown. 
doctor and the philosopher. ${ }^{91}$ In fact, according to the philosopher from Soloi, as Galen distinctly states in his previously mentioned treatise, their comparative similarity is evident: "I believe in both the similarity of the treatments and in the existing analogy between the two therapeutic arts (i.e. medicine and philosophy), that is, "the analogy between the two medical methods." ${ }^{2}$

${ }^{91}$ Gal. PHP V 2, 23-24 De Lacy (= SVF III 471),: "just as the doctor of the body must be in the diseases that occur and give the appropriate treatment in each case, so it is imperative for the doctor of the soul to be in both capacities to the best of his abilities".

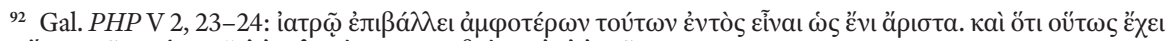

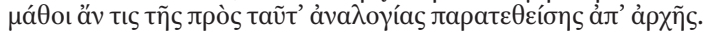




\section{BIBLIOGRAPHY:}

Baloyannis, S. J., 2006, “Galen on the functional expression of the soul by the brain,” Encephalos. Archives of Neurology and Psychiatry 43 [1], http://www.encephalos.gr/43-1-01e.htm [the last access: 06.11.2020].

Barras, V., Birchler, T., 1994, “La perfection de l'homme chez Galien,” Equinoxe 11, pp. 27-36.

BAzou, A. (ed.), 2011, Galenos, Hoti tais tou somatos krasesin ai tes psyches dynameis hepontai, Athens.

BEKKER, I. (ed.), 1854, Suidae lexicon, Berlin.

Boudon, V. (ed.), 2002, Galien, Exhortation à l'étude de la medicine. Art medical, Paris.

Boudon-Millot, V., 2000, “Galien,” in: Dictionnaire des philosophes antiques, R. Goulet (dir.), Paris, pp. $440-466$.

Boudon-Millot, V., Jouanna, J. (ed.), 2010, Galien, Ne pas se chagriner, Paris.

BrÉHIER, É., 1971, Chrysippe et l'ancien Stö̈cisme, Paris-Londres-New York.

Chauvet, E., 1857, Mémoire sur le Traité de Galien: des Dogmes d'Hippocrate et de Platon, Paris.

Cornford, F. M., 1937, Plato's Cosmology, London.

DARAKI, M., 1989, Une religiosité sans Dieu. Essais sur les Stoïciens d'Athènes et saint Augustin, Paris.

Daremberg, CH., 1848, Fragments du commentaire de Galien sur le Timée de Platon, Paris-Leipzig.

Daremberg, Ch., Ruelle, É., 1879, Ouvres de Rufus d'Éphèse, Paris.

De Boer, W. (ed.), 1937, De priopriorum animi cuiuslibet dignotione et curatione, Leipzig-Berlin.

DE LACY, Ph. (ed.), 1981, On the Doctrines of Hippocrates and Plato, Berlin.

Frede, M., 1974, “Stoic vs. Aristotelian syllogistic," Archiv für Geschichte der Philosophie 56, pp. 1-32.

Gourinat, J. B., 2017, Les Stö̈cens et l'âme, Paris.

Grafton, A., Most, G. W., Settis, S., 2010, The Classical Tradition, Cambridge-London.

Hankinson, J., 2009, “Actions and Passions: Affection, Emotion, and Moral self-management in Galen's Philosophical Psychology," in: J. Brunschwig, M. Nusbaum (eds.), Passions and Perceptions, Studies in Hellenistic Philosophy of Mind, pp. 184-222.

Helmreich, G. (ed.), 1907-1909, Galeni de usu partium libri, Leipzig [Amsterdam 1968].

Hicks, R. D. (ed.), 1958, Diogenes Laertius, Lives of Eminent Philosophers, vol. I-II, London-Cambridge.

Klibansky, R., Panofsky, E., SAxl, F., 1989, Saturne et la mélancolie, Paris.

Kneale, W., Kneale, M., 1962, The Development of Logic, Oxford.

Kreuttner, X., 1885, Andronicus Rhodius, De passionibus, Heidelberg.

Liddell, H. G., ScotT, R., 1996, A Greek-English Lexicon, Oxford.

Manuli, P., 1992, “Galien et le Stoïcisme,” Revue de Métaphysique et de Morale 97 [3], pp. 365-375.

Mates, B., 1953, Stoic Logic, Berkeley.

Mignucci, M., 1972, Il significato della logica stoica, Bologna.

Miller, H. W., 1962, “The Aetiology of Disease in Plato's Timaeus,” Transactions of the American Philological Association 93, pp. 175-187.

Mirhady, D. (ed.), 2011, Aristotle, Problems. Books 20-38, Cambridge.

Moraux, P. (ed.), 1985, Galien de Pergame, Souvenirs d'un médecin, Paris.

Moraux, P., 1976, "Galien et Aristote," in: F. Bossier et alii (ed.), Images of Man in Ancient and Medieval Thought. Studia Gerardo Verbeke ab amicis et colleges dicata, Leuven, 1976, pp. 127-146.

Moraux, P., 1981, “Galien comme philosophe: la philosophie de la nature,” in V. Nutton (ed.), Galen. Problems and Prospects, Cambridge, pp. 87-116 
Moutsopoulos, E., 1991, La mise et l'enjeu, Paris.

Nickel, D. (ed.), 2001, Galeni de foetum formatione, Berlin.

Northwood, H., 1998, “The Melancholic Man: The Aristotelian Problema XXX.1,” Paideia. Ancient Philosophy, https://www.bu.edu/wcp/Papers/Anci/AnciNort.htm [last access: 08.11.2020].

Petit, C. (ed.), 2009, Galien, Le médecin. Introduction, t. 3, Paris.

Pigeaud, J., 1988, “La psychopathologie de Galien,” in: P. Manuli, M. Vegetti (cur.), Le opere psicologiche di Galeno, Napoli, pp. 153-183.

Pigeaud, J., 2006a, Aristote, L’homme de génie et la mélancolie, Paris.

Pigeaud, J., 2006b, La maladie de l'âme. Étude sur la relation de l'âme et du corps dans la tradition médico-philosophique antique, Paris.

Pohlenz, M., 1963, La libertà greca, M. Bellicioni (trad.), Brescia.

Schunl, P.-M. (dir.), 1962, Les Stoüciens. Cléanthe. Diogène Laërce. Plutarque. Cicéron. Sénèque. Épictète. Marc-Aurèle, É. Brehier et al. (trad.), Paris.

Singer, P. N., 2018, “Galen's Pathological Soul: Diagnosis and Therapy in Ethical and Medical Texts and Contexts," in: C. Thumiger, P. N. Singer (eds.), Mental Illness in Ancient Medicine, from Celsius to Paul of Aegina, Leiden-Boston, pp. 381-420.

Singer, P. N. (ed.), 2013, “Introduction,” in: Galen, Psychological Writings, Cambridge, pp. 205-236.

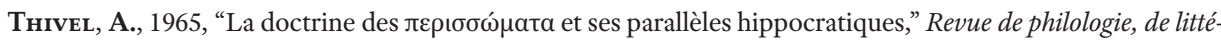
rature et d'histoire anciennes 39, pp. 266-282.

Tieleman, T., 2003, Chrysippus' On Affections. Reconstruction and Interpretation, Leiden-Boston.

WAlz, CH., 1834, Rhetores Graeci, vol. VII, Stutgart-Tübingen.

ZAHARIA, C., 2003, La parole mélancolique. Une archéologie du discours fragmentaire, University of Bucharest. 
MARIA PROTOPAPAS-MARNELI

/ Academy of Athens, Greece /

marproto@academyofathens.gr
The Affections of the Soul according to Aristotle, the Stoics and Galen: On Melancholy

The present article is divided into two parts: the first focuses on the affections of the soul in general, while the second part investigates the case of melancholy, as it is studied from Aristotle and the Stoics to Galen. The main point of the first part is an analysis of the Chrysippean treatise On the Affections of the Soul as it appears in the Galenic treatise On the Doctrines of Hippocrates and Plato. The analysis identifies several Chrysippean influences from Plato and Aristotle regarding the psyche. In the second part, the case of melancholy is analyzed through the pseudo-Aristotelian treatise Problem XXX 1. The discussion shows the common points between the Aristotelian text and the Chrysippean fragments regarding the issue of melancholy. This article aims to bring to light the evolution of the phenomenon of melancholy in Galen's thought, which is connected with the study of both medical and philosophical texts already existing before him.

affections, illness, humors, symmetry, soul, melancholy 